\title{
Nutritional constituents and antioxidant properties of indigenous kembayau (Dacryodes rostrata (Blume) H. J. Lam) fruits.
}

\begin{abstract}
The nutritional and antioxidant properties of peels, pulp and seeds of kembayau (Dacryodes rostrata) fruits were evaluated. Kembayau seeds and pulp were rich in fat, while peels had the highest ash contents. Potassium was the most prevalent mineral in peels (380.72$1112.00 \mathrm{mg} / 100 \mathrm{~g})$. In kembayau fruits, total flavonoid content $(1012.74-28,022.28 \mathrm{mg}$ rutin equivalent $/ 100 \mathrm{~g}$ ) was higher than total phenolic and total monomeric anthocyanin contents. Kembayau seeds exhibited high flavonoid and phenolic contents compared to the contents in peels and pulp. Antioxidant capacities were also higher in seeds as typified by trolox equivalent antioxidant capacity assay $(51.39-74.59 \mathrm{mmol} \mathrm{TE} / 100 \mathrm{~g})$, ferric reducing antioxidant power assay $(530.05-556.98 \mathrm{mmol} \mathrm{Fe} 2+/ 100 \mathrm{~g})$ and by 1,1-diphenyl-2-picryl hydrazyl radical scavenging activity $(92.18-92.19 \%)$ when compared to peels and pulp. Pulp and peels of kembayau fruit may be an important source of energy and minerals for human consumption, while seeds have a good potential as antioxidants.
\end{abstract}

Keyword: Antioxidants; Dacryodes rostrata; Minerals; Polyphenols; Underutilised fruit. 